Article

\title{
Size-Segregated Chemical Compositions of HULISs in Ambient Aerosols Collected during the Winter Season in Songdo, South Korea
}

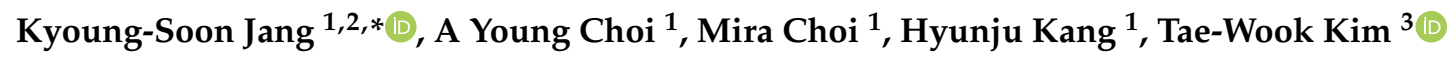 \\ and Ki-Tae Park $4, *$ (D) \\ 1 Biomedical Omics Center, Korea Basic Science Institute, Cheongju 28119, Korea; \\ ayoung3132@kbsi.re.kr (A.Y.C.); alfk6346@kbsi.re.kr (M.C.); hied1235@kbsi.re.kr (H.K.) \\ 2 Division of Bio-Analytical Science, University of Science and Technology, Daejeon 34113, Korea \\ 3 Division of Environmental Science and Ecological Engineering, Korea University, Seoul 02841, Korea; \\ kimtwk@korea.ac.kr \\ 4 Korea Polar Research Institute, Incheon 21990, Korea \\ * Correspondence: ksjang@kbsi.re.kr (K.-S.J.); ktpark@kopri.re.kr (K.-T.P.); Tel.: +82-43-240-5196 (K.-S.J.); \\ +82-32-760-5608 (K.-T.P.)
}

Received: 25 March 2019; Accepted: 24 April 2019; Published: 25 April 2019

\begin{abstract}
The primary objective of this study was to investigate the molecular compositions of humic-like substances (HULISs) in size-resolved ambient aerosols, which were collected using an Anderson-type air sampler (eight size cuts between 0.43 and $11 \mu \mathrm{m}$ ) during the winter season (i.e., the heating period of 8-12 January 2018) in Songdo, South Korea. The aerosol samples collected during the pre- (preheating, 27 November-1 December 2017) and post-winter (postheating, 12-16 March 2018) periods were used as controls for the winter season samples. According to the concentrations of the chromophoric organics determined at an ultraviolet (UV) wavelength of $305 \mathrm{~nm}$, most of the HULIS compounds were found to be predominantly enriched in particles less than $2.1 \mu \mathrm{m}$ regardless of the sampling period, which shows that particulate matter (diameter less than $2.5 \mu \mathrm{m} ; \mathrm{PM}_{2.5}$ ) aerosols were the dominant carriers of airborne organics. Ultrahigh-resolution Fourier transform ion cyclotron resonance mass spectrometry (UHR FT-ICR MS) analysis of the aerosol-carried organic substances revealed that as the aerosol size increased the proportions of $\mathrm{CHO}$ and nitrogen-containing $\mathrm{CHO}(\mathrm{CHON})$ compounds decreased, while the proportion of sulfur-containing $\mathrm{CHO}$ (CHOS) species increased. In particular, the ambient aerosols during the heating period seemed to present more $\mathrm{CHO}$ and $\mathrm{CHON}$ and less $\mathrm{CHOS}$ molecules compared to aerosols collected during the pre- and postheating periods. The aerosols collected during the heating period also exhibited more aromatic nitrogen-containing compounds, which may have originated from primary combustion processes. Overall, the particle size distribution was likely influenced by source origins; smaller particles are likely from local sources, such as traffic and industries, and larger particles (i.e., aged particles) are likely derived from long-range transport generating secondary organic aerosols (SOAs) in the atmosphere. The results of the size-segregated particles can be utilized to understand particle formation mechanisms and shed light on their toxicity to human health.
\end{abstract}

Keywords: HULIS; size-segregated; FT-ICR MS; PM 2.5; source origins

\section{Introduction}

Air pollution is a serious environmental issue, particularly in East Asian countries, such as China and Korea [1,2]. Ambient aerosols are composed of primary organic aerosols (POAs), which are generated by coal combustion, traffic, biomass burning, and/or industrial processes and emitted into the atmosphere, and secondary organic aerosols (SOAs) [3,4]. In particular, SOAs, which are 
mainly formed in the ambient phase by the chemical transformation of atmospheric primary organic compounds [3,5], have been considered to be an important constituent of ambient aerosols. Their formation mechanisms have been gaining increasing attention because they largely affect human health due to their severe toxicity [6-9].

A molecular level description of atmospheric organic aerosols is needed to better understand the impact of aerosols on human health and our ecosystems. In particular, aerosol-carried water-soluble organic matter are often classified as humic-like substances (HULISs) that have properties similar to naturally occurring humic and fulvic acids [10]. Airborne HULISs have been shown to play significant roles in several areas of atmospheric systems, ranging from air quality to global biogeochemical cycles and climate systems $[10,11]$. Furthermore, the chemical compositions of ambient HULISs vary according to the sources of aerosol constituents and formation mechanisms [12-17]. However, elucidating the detailed chemical compositions and structural information of HULISs at the molecular level is challenging due to the extremely high variety and complexity of chemical compositions. HULISs typically consist of thousands of compounds from a wide range of compound classes and originate from a variety of sources.

In the present study, ambient particles were collected using an Anderson cascade impactor and the HULIS samples were investigated using a 15 Tesla Fourier transform ion cyclotron resonance (FT-ICR) mass spectrometer (MS), in order to understand chemical changes based on the sizes of the particulate matter. The resulting data were interpreted to characterize the chemical compositions of the organic substances in the fine particles. Based on the chemical compositions and properties of the size-resolved particles, we could predict their source origins. This in-depth chemical characterization of size-dependent organic molecules in atmospheric aerosols provides further insight into the nature of airborne pollutants and new particle formation events.

\section{Experiments}

\subsection{Aerosol Sampling}

Airborne particles were collected using an Andersen-type air sampler (AN-200, Sibata, Tokyo, Japan) with eight stages for the collection of size-resolved ambient particles (eight size cuts between 0.43 and $11 \mu \mathrm{m}$ ). Samples were collected in the Songdo district of South Korea, a coastal area located southwest of Seoul, the capital city. The air sampler was mounted on the roof of the Department of Marine Science, Incheon National University $\left(37.4^{\circ} \mathrm{N}, 126.6^{\circ} \mathrm{E}\right)$ and the sampling site was surrounded by the Incheon international airport, a port, an industrial complex, a local heating facility, a residential area, and oceans, thereby resulting in a complex mixture of a pollution source origins.

Particulate matter (PM) aerosols were collected on a Teflon filter ( $\varphi 80$, Sibata) using the Anderson-type impactor in November 2017, January 2018, and March 2018, according to the manufacturer's instructions. Five day sampling times were employed in order to be unaffected by synoptic-scale changes due to weather conditions $[18,19]$, thus aerosol samples collected during the study period could reflect molecular characteristics of both long-range transported and local sources. The suction flow rate was $28.3 \mathrm{~L} \mathrm{~min}^{-1}$. The Teflon sample filters were segregated by size $(0.43-0.65$, $0.65-1.1,1.01-2.1,2.1-3.3,3.3-4.7,4.7-7.0,7.0-11.0$, and $>11.0 \mu \mathrm{m}$ ). Field blank filter samples were prepared as a control. After collection, the sample filters were stored at $-20{ }^{\circ} \mathrm{C}$ until analysis. Basic air quality information, including the $\mathrm{PM}_{10}$ and $\mathrm{PM}_{2.5}$ levels, was provided by the Air Korea website (http://www.airkorea.or.kr) operated by the Korean Ministry of the Environment (KME).

\subsection{Preparation of HULISs from Size-Segregated Aerosols}

The HULISs, which was first coined by Havers et al. [20], can be extracted in alkali solution, followed by gel permeation chromatography or dialysis. However, for atmospheric samples collected in this study we adopted the water extraction followed by C18-based solid-phase extraction, first established by Varga et al. [21]. The extraction of HULISs from the size-segregated aerosol samples was conducted 
according to the method described by Lin et al. [13,22], with minor modifications. Briefly, each Teflon filter (ca. $150 \mathrm{~cm}^{2}$ ) was placed in ultrapure water $(20 \mathrm{~mL})$ to extract organic substances in a sonication bath for $1 \mathrm{~h}$. The extract was filtered using a $0.45 \mu \mathrm{m}$ Teflon syringe filter, which was followed by acidification to a $\mathrm{pH}$ of 2 using $1 \mathrm{M} \mathrm{HCl}$. After this, the extract was loaded on a solid phase extraction (SPE) cartridge (Oasis Hydrophilic-Lipophilic Balance (HLB), Waters, Milford, MA, USA). Prior to loading the samples, the cartridge was first conditioned with $3 \mathrm{~mL}$ of methanol, which was followed by $3 \mathrm{~mL}$ of $0.1 \%$ formic acid. After loading the samples, the cartridge was washed with $1 \mathrm{~mL}$ of ultrapure water three times and the organic species retained on the cartridge were subsequently eluted with methanol containing $2 \%$ ammonium hydroxide $(0.5 \mathrm{~mL} \times 2)$. The resultant samples were dried under a gentle nitrogen stream and redissolved with $50 \%$ aqueous methanol containing $7 \%$ ammonium hydroxide solution for Fourier transform mass spectrometry (FT MS) with negative ion mode analysis. Approximately $60 \%$ of the HULIS extracts were expected to be recovered from the SPE procedure [21]. A field blank filter extract was also prepared for a control experiment.

\subsection{FT-ICR MS Analysis and Data Processing for Elemental Composition Assignments}

The size-resolved chemical compositions of the HULISs, extracted from the aerosols that were collected during the winter season (January 2018), were investigated using an ultrahigh-resolution (UHR) FT-ICR mass spectrometer. The other samples collected in November 2017 and March 2018 were also investigated to determine any eventual differences connected to seasonal variations. To obtain the elemental compositions for the aerosol-derived organic substances, UHR mass spectra were acquired using a 15 T FT-ICR mass spectrometer (solariX XR ${ }^{\mathrm{TM}}$ system, Bruker Daltonics, Billerica, MA, USA) equipped with a standard electrospray ionization (ESI) interface, as previously demonstrated [23,24]. The HULIS extracts were directly infused into the mass spectrometer at a flow rate of $2 \mu \mathrm{L} \mathrm{min}^{-1}$ using a syringe pump and analyzed in negative ion mode at a capillary voltage of $3.5 \mathrm{kV}$. The lower and upper mass limits were set to mass-to-charge $(\mathrm{m} / \mathrm{z})$ values of 150 and 1000, respectively. The drying gas flow rate was held at $4 \mathrm{~L} \mathrm{~min}^{-1}$; the drying gas temperature was held at $200{ }^{\circ} \mathrm{C}$; the ion accumulation time was held at $0.01 \mathrm{~s}$; and the transient length was held at $1.39 \mathrm{~s}$, for all experiments. Two hundred scans, with $4 \mathrm{M}$ words of data, were collected per sample, resulting in a mass resolving power greater than 500,000 (at $\mathrm{m} / \mathrm{z} 400$ ). The instrument was externally calibrated using a sodium trifluoroacetate (NaTFA) solution ( $10 \mu \mathrm{g} / \mathrm{mL}$ in $50 \%$ aqueous methanol) prior to the sample analysis. Data acquisition was controlled by the ftmsControl 2.0 software (Bruker Daltonics).

After the acquisition of FT MS spectra by the 15 T FT-ICR MS, the datasets were processed using the DataAnalysis (ver. 4.2, Bruker Daltonics) and Composer (Sierra Analytics, Modesto, CA, USA) software to assign the elemental compositions, as previously described [25]. Briefly, the formula calculator, Composer, was used to calculate the empirical molecular formulae from the masses of singly charged ions extracted from the raw spectra in the range of $m / z 150-1000$. Constraints on the maximum number of atoms were set to $100{ }^{12} \mathrm{C}, 200{ }^{1} \mathrm{H}, 50{ }^{16} \mathrm{O}, 4{ }^{14} \mathrm{~N}$, and $2{ }^{32} \mathrm{~S}$ atoms for the calculations of the molecular formula. After this, the molecular formulas with assignment errors $>0.3 \mathrm{ppm}$ and those from the blank filter extract were excluded from the final list. A van Krevelen plot was used to visualize the assigned chemical compositions based on the atomic hydrogen-to-carbon $(\mathrm{H} / \mathrm{C})$ and oxygen-to-carbon $(\mathrm{O} / \mathrm{C})$ ratios (Section 3.2) [26]. The double bond equivalent (DBE) value representing the sum of the rings and double bonds in each molecule (the degree of unsaturation in a given compound) was calculated from the number of atoms in the chemical formulas using the following rule: $D B E=1+n_{C}-0.5 n_{H}+0.5 n_{N}$ [27]. The potential presence of aromatic structures in a molecule can also be interpreted based on the aromaticity index (AI) [28].

\subsection{Air Mass Backward Trajectory Analysis}

Air mass backward trajectories and meteorological parameters, including the marine boundary layer, were calculated using the hybrid single-particle Lagrangian integrated trajectories (HYSPLIT) model [29]. Three-day backward trajectories arriving at the sampling site were estimated at hourly 
intervals during each sampling period, to identify the potential source areas for the observed properties of aerosol particles. A cluster analysis that included the HYSPLIT model was performed to identify general air mass transportation patterns over the three sampling periods.

\section{Results and Discussion}

\subsection{Size-Segregated Sampling of Ambient Aerosols during the Winter Season in Songdo, South Korea}

Measurements of the concentrations of chromophoric organic molecules in the aerosol extracts at an ultraviolet (UV) wavelength of $305 \mathrm{~nm}$ were used to estimate the organic carbon concentrations of the size-resolved particles [30,31]. According to the concentrations of the chromophoric organics in the HULISs (Figure 1), a significant proportion of the organic substances in the atmospheric aerosols were composed of particles less than $2.1 \mu \mathrm{m}$ in size, regardless of the sampling period. This result shows that $\mathrm{PM}_{2.5}$ aerosols are the dominant carriers of airborne particulate matter. The size distribution of fine organic aerosols was consistent with the previous reports, which found that the sizes of various airborne particles ranged from $10 \mathrm{~nm}$ to $20 \mu \mathrm{m}$ [32-34]. However, the lower size limit was determined as $0.43 \mu \mathrm{m}$ in our measurements (as shown in Figure 1). In particular, the aerosol-derived organic concentration collected in January shows a lower proportion in the smallest particles (those with size less than $0.65 \mu \mathrm{m}$ ) than those collected in November and March. This results in a more narrow size distribution with a maximum at the size of $0.65-1.1 \mu \mathrm{m}$ during the heating period. In contrast, the samples from the other periods show relatively broader distributions, exhibiting equivalent amounts of the chromophoric organics at the finest size $(0.43-0.65 \mu \mathrm{m})$. Given these observations of the particle size distribution, it was assumed that the fine particles with a diameter between 0.65 and $1.1 \mu \mathrm{m}$ account for the majority of the organic aerosols collected during the heating season, while finer particles less than $0.65 \mu \mathrm{m}$ seem to exhibit more proportions of the aerosols collected during pre- and postheating periods.

(a)

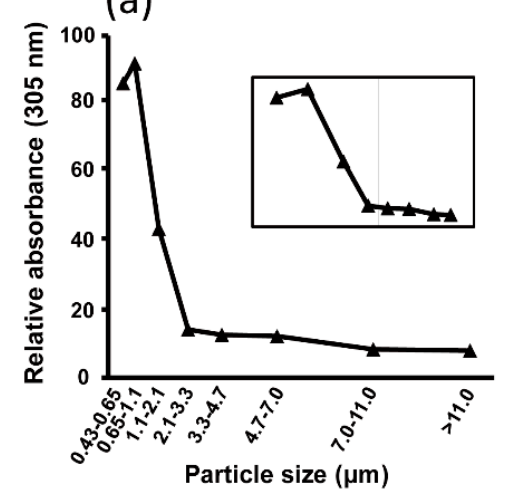

(b)

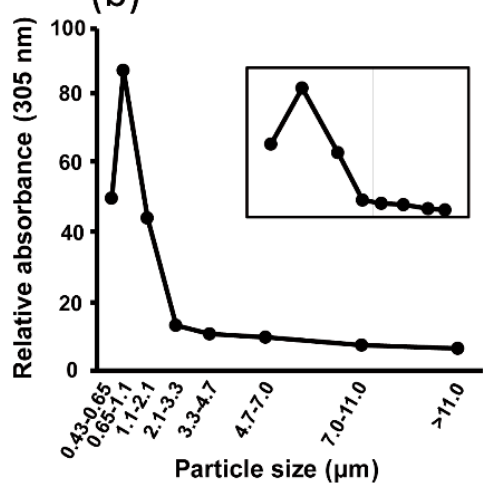

(c)

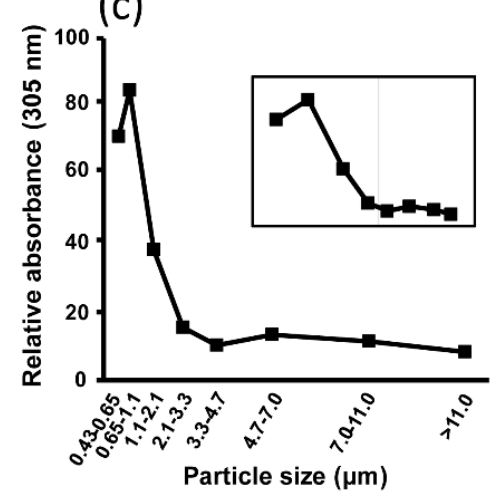

Figure 1. Ultraviolet (UV) absorbance profile of size-segregated aerosols collected during different periods: (a) November, preheating period; (b) January, heating period; and (c) March, postheating period. The data points of the $\mathrm{x}$-axis were determined by the midpoint of each range of particle sizes. The insets show the corresponding distributions with a log-scaled $x$-axis for particle size.

\subsection{UHR FT-ICR MS Profiles of HULISs in Size-Segregated Aerosols}

The HULIS extracts of the size-resolved aerosol samples were analyzed using a UHR 15 T FT-ICR mass spectrometer equipped with an ESI source. The FT-ICR MS was performed in the negative ion mode due to the intrinsic properties of HULISs, which mostly possess hydroxyl and carboxyl functional groups. After processing the raw data using the elemental formula calculator, 1059 to 3052 chemical formulas of the total organic substances were assigned to the data. The overall chemical attributes of the size-resolved HULISs are shown in Figure 2 and summarized in Supplementary Materials Table S1. 
Regardless of the sampling periods, we observe an increase in the DBE, AI, and nitrogen-to-carbon $(\mathrm{N} / \mathrm{C})$ ratios as particle size is decreased from larger particles $(\sim 11 \mu \mathrm{m})$ to very small particles $(\sim 0.43 \mu \mathrm{m})$. On the other hand, the hydrogen to carbon $(\mathrm{H} / \mathrm{C})$ and sulfur-to-carbon $(\mathrm{S} / \mathrm{C})$ ratios decrease as particle size is decreased (Figure 2). The higher DBE and AI values of organic substances in smaller particles may represent heavier proportions of unsaturated and/or aromatic molecules in the fine particles. Furthermore, the higher N/C ratio and lower S/C and H/C ratios of the HULISs are indicative of higher nitrogen-substitution, lower sulfur-substitution, and alkylation for the smaller particles, which implies that nitrogen-containing compounds with condensed structure (e.g., aromatic amines) are the majority of the total organic particles.

(a)

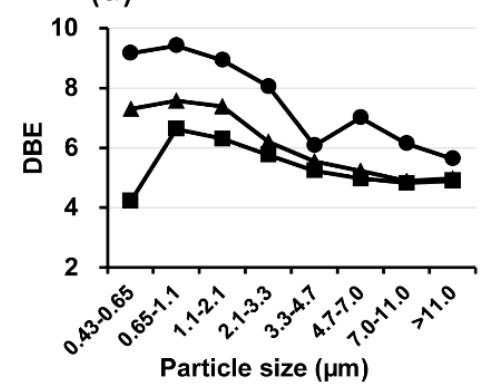

(d)

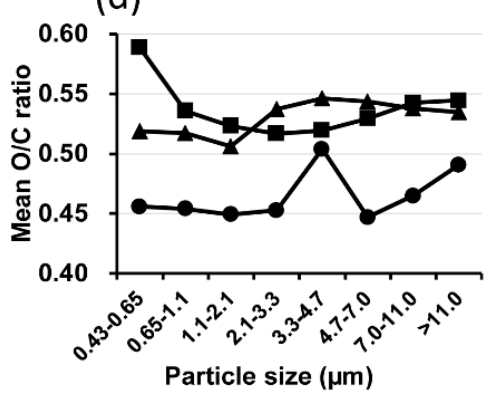

(b)

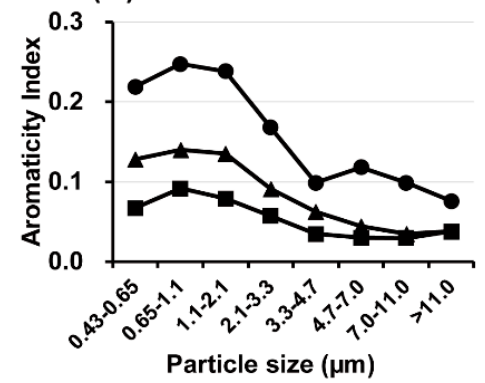

(e)

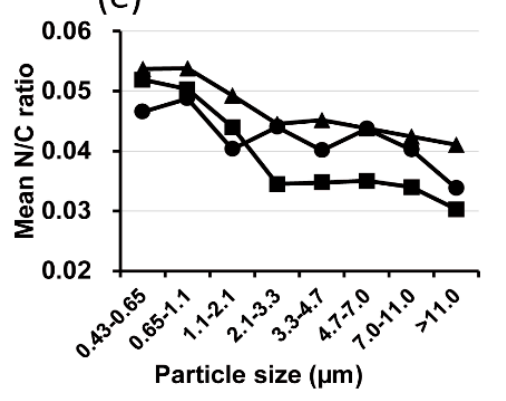

(c)

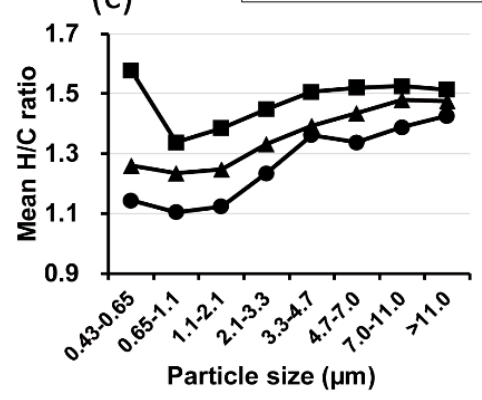

(f)

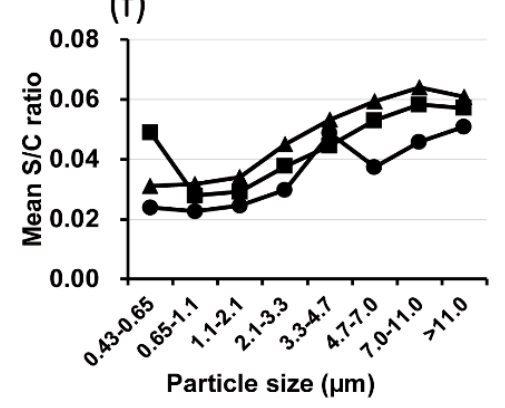

Figure 2. Comparison of the chemical properties of humic-like substances (HULISs) in size-segregated aerosols: (a) the double bond equivalent (DBE); (b) aromaticity index (AI); and the mean (c) hydrogen-to-carbon (H/C), (d) oxygen-to-carbon $(\mathrm{O} / \mathrm{C})$, (e) nitrogen-to-carbon $(\mathrm{N} / \mathrm{C})$, and (f) sulfur-to-carbon $(\mathrm{S} / \mathrm{C})$ ratios.

The mean $\mathrm{O} / \mathrm{C}$ ratio shows no significant trend over the particle sizes, but differs among the sampling periods. A lower $\mathrm{O} / \mathrm{C}$ ratio was observed from aerosols during the heating season compared to those in other periods (Figure 2d). A higher $\mathrm{O} / \mathrm{C}$ ratio for airborne organic species likely reflects higher oxidation states and the presence of SOAs, since gas-phase aerosol oxidation is significantly associated with SOA formation mechanisms and particle formation and growth [5,35]. The gas-phase oxidation level could be facilitated with atmospheric humidity [36,37]. However, the mean relative humidity at the sampling site was not significantly different among the sampling periods in this study (see Supplementary Materials Table S2). Given these observations, the lower $\mathrm{O} / \mathrm{C}$ ratio of the organic aerosols collected during the heating period provides evidence for a higher proportion of POAs, which originated from primary combustion emissions, and for a relatively smaller SOA content in the heating season aerosols.

According to the chemical class distributions of the ambient HULISs (Figure 3), the proportion of sulfur-containing $\mathrm{CHO}(\mathrm{CHOS})$ species increases while the proportions of $\mathrm{CHO}$ and nitrogen-containing $\mathrm{CHO}(\mathrm{CHON})$ compounds decreases as the sizes of aerosols increase. This suggests that $\mathrm{CHO}$ and $\mathrm{CHON}$ molecules are more likely to be enriched in fine PM. In particular, ambient aerosols during the main heating period present more $\mathrm{CHO}$ and $\mathrm{CHON}$ molecules and fewer $\mathrm{CHOS}$ molecules compared to the aerosols collected during the pre- and post-heating periods. Essentially, the $\mathrm{CHO}$ 
and $\mathrm{CHON}$ classes are the dominant contributors of HULISs during the heating period, accounting for $25 \%$ (CHO species) and $25 \%$ (CHON species) of $\mathrm{PM}_{2.5}$, whereas the CHOS class compounds were the most substantial contributor during the pre- and post-heating periods along with nitrogen and sulfur-containing $\mathrm{CHO}$ (CHONS) compounds.

(a)

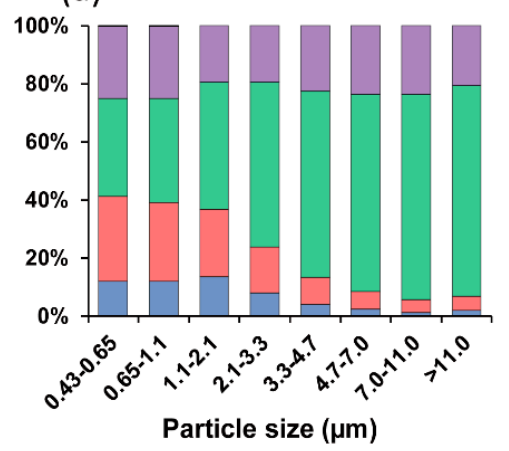

(b)

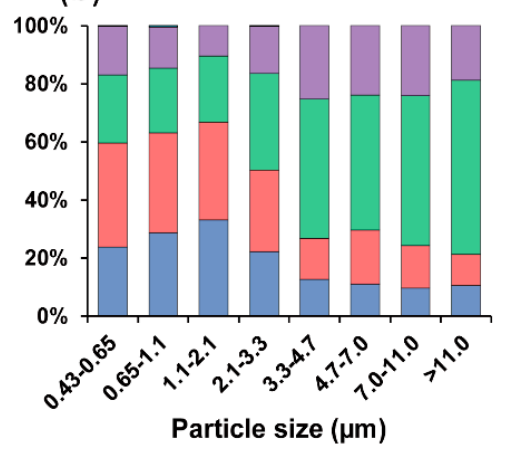

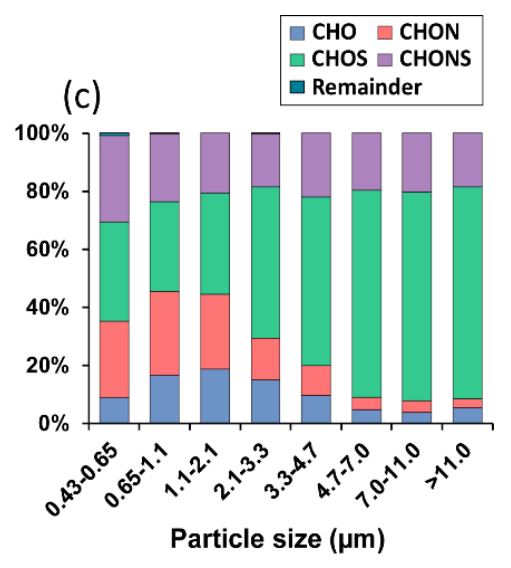

Figure 3. Size-segregated distributions of chemical classes of ambient aerosol-derived HULISs collected during the (a) preheating, (b) main-heating, and (c) postheating periods (color code: $\mathrm{CHO}$, blue; nitrogen-containing $\mathrm{CHO}(\mathrm{CHON})$, red; sulfur-containing $\mathrm{CHO}(\mathrm{CHOS})$, green; nitrogen and sulfur-containing $\mathrm{CHO}(\mathrm{CHONS})$, purple; remainder, dark green).

We also found that the $\mathrm{CHO}$ and $\mathrm{CHON}$ species contributed more to the overall DBE and AI values of the HULISs, with their contributions being more substantial in smaller particles (see Supplementary Materials Tables S3-S5). Together, these oxygen- and nitrogen-containing organic species are supposed to be the main constituents of airborne fine particles (less than $2.1 \mu \mathrm{m}$ in size) and are the result of primary emissions. This suggests the strong possibility that oxygen and nitrogen-containing organic molecules originate from anthropogenic sources, such as fossil-fuel combustion events, and show distinct seasonal variations.

\subsection{Seasonal Characteristics of Ambient Size-Resolved HULIS Samples}

In order to determine the key compound classes that are responsible for the seasonal characteristics of organic aerosols, we investigated the composition-specific chemical properties from the FT MS datasets (see Supplementary Materials Tables S3-S5). The DBE and AI values of $\mathrm{CHO}$ and $\mathrm{CHON}$ compounds observed from aerosols that were collected during the main heating period were higher than those from other sampling periods. CHON compound classes from the pre-, main-, and post-heating samples exhibited mean DBE/AI values of 7.10/0.16, 9.04/0.24, and 6.25/0.08, respectively, which suggests a significant contribution to the nitrogen-containing molecules from primary combustion product emissions during the heating period. This trend also correlated with the $\mathrm{CHO}$ class species. We also observed strong negative correlations of the DBE and AI values $\left(r^{2}=0.89\right.$ and 0.79 for $\mathrm{CHO}, r^{2}=0.89$ and 0.99 for CHON, respectively) with the particle size during the heating season (Supplementary Materials Figures S2 and S3 and Tables S3-S5). This is reflective of the organonitrates from primary emissions and are the significant contributor for the accumulation in the fine particles during the heating period.

SOA is often considered to be a major contributor to total HULIS through various photochemical reactions of primary precursors (e.g., oxidation and condensation). The high $\mathrm{O} / \mathrm{C}$ ratio of aerosol-derived organic substances can be a good indicator for SOA formation $[5,35]$. The mean $\mathrm{O} / \mathrm{C}$ ratios of $\mathrm{CHO}$ and CHOS compounds did not change over the sampling periods, irrespective of the aerosol size, while the mean $\mathrm{O} / \mathrm{C}$ ratio of $\mathrm{CHON}$ species during the heating period was smaller than those in the preand postheating periods. This provides evidence for the elevated proportion of primarily emitted 
nitrogen-containing organics with a less oxidized state, in aerosols collected during the heating period (Supplementary Materials Figures S2-S4).

No significant correlation was observed between the DBE and AI values of CHOS species and the particle size over the sampling periods (Supplementary Materials Figure S4), which implies the sulfur-containing compounds are not likely associated with seasonal variation. According to the relatively smaller values of DBE and AI of $\mathrm{CHOS}$ compounds in the ranges of 4-6 and $0.03-0.06$, respectively-compared to $6-12$ and $0.05-0.4$ for $\mathrm{CHO}$, and 5-11 and 0.05-0.35 for $\mathrm{CHON}$ - the sulfur-containing organic molecules seem to be more saturated and have an aliphatic nature. Together, the CHOS compounds, which exhibit an abundance of 1-2 DBEs and 6-10 carbons, are likely obtained from biogenic sources (i.e., isoprene and monoterpenes; refer to Supplementary Materials Figure S5). This is consistent with the previous literature describing organosulfates in HULIS, which is the main constituent in SOAs [38].

The distribution of specific classes of organic compounds that are present in HULISs from different sampling periods can be explained by van Krevelen plots. The representative van Krevelen diagrams displaying the compound classes of the HULISs in particles between 1.1 and $2.1 \mu \mathrm{m}$ (stage 3 fractions) in the pre-, main-, and post-heating periods are shown in Figure $4 a-c$, respectively. According to the proportion of each compound class, the organic compounds in the main-heating period aerosols mainly belong to lignins and condensed aromatics, whereas the organics from the aerosols collected during the pre- and post-heating periods possessed higher proportions of proteins and carbohydrate species (Figure 5). The lignin class species is often considered to be derived from plant or wood sources [39] and condensed aromatics are a major contributor of primary combustion emissions [40,41]. Therefore, the higher proportions of these compound classes (lignins and condensed aromatics) are indicators of household heating or coal combustion events that mostly occurred during the main-heating period. Moreover, among the molecular classes, lignins contribute more to the higher DBE and AI values of the organic aerosols (Figure 5), except for condensed aromatics. Furthermore, strong negative correlations were found as the particle size increased, particularly during the heating period (Supplementary Materials Tables S6-S8). Thereby supporting that the lignin class may be the most significant contributor of the HULIS during the heating period. Carbohydrate class species exhibited the second largest proportion of the HULISs (Figure 5), but the chemical properties of the compounds presented no significant features over the sampling periods and sizes (see Supplementary Materials Tables S6-S8). 
(a)

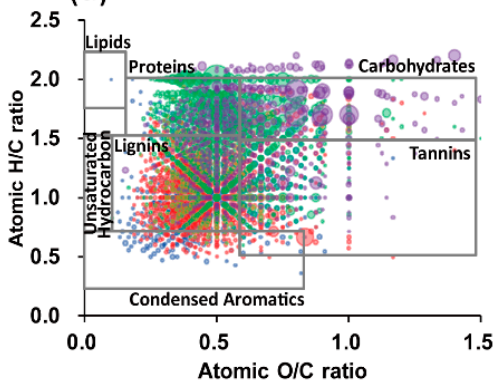

(d)

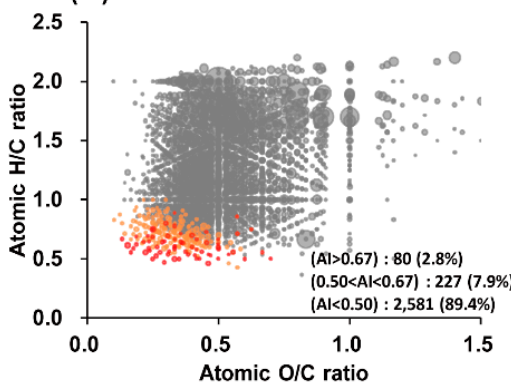

(b)

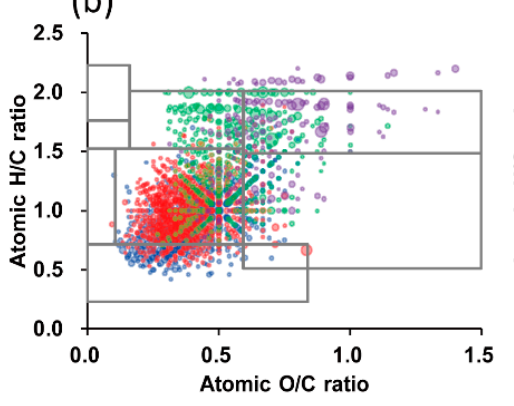

(e)

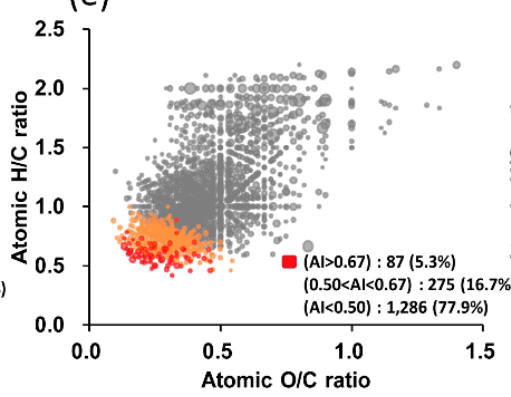

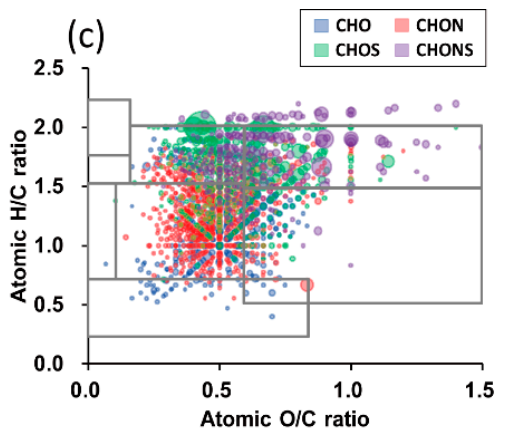

(f)

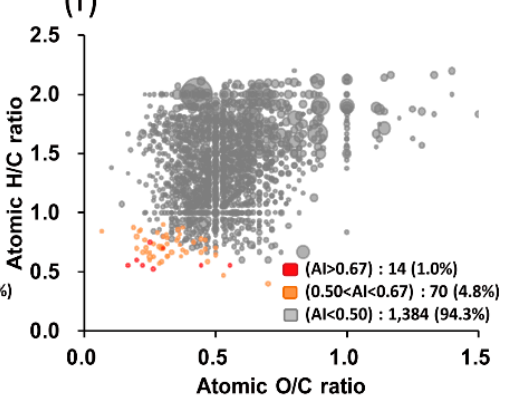

Figure 4. Van Krevelen plots showing the distribution of chemical classes based on the molar $\mathrm{H} / \mathrm{C}$ and $\mathrm{O} / \mathrm{C}$ ratios for the assigned elemental compositions of the size-segregated aerosol-derived HULISs, which were analyzed by electrospray ionization (ESI) Fourier transform ion cyclotron resonance mass spectrometry (FT-ICR MS), in the stage three fractions (size cut: 1.1-2.1 $\mu \mathrm{m}$ ) during different sampling periods for $(\mathbf{a}-\mathbf{c})$, showing the molecular compound classes. Color code: $\mathrm{CHO}$, blue; $\mathrm{CHON}$, red; $\mathrm{CHOS}$, green; and CHONS, purple. (d-f) Represent the presence of aromatic species (color code: $\mathrm{AI}<0.5$, gray; $0.5<\mathrm{AI}<0.67$ orange; $\mathrm{AI}>0.67$, red). $(\mathbf{a}, \mathbf{d})$ preheating, $(\mathbf{b}, \mathbf{e})$ main heating and $(\mathbf{c}, \mathbf{f})$ postheating periods. The size of each circle is proportional to the intensity of the molecular formula.

The presence of aromatic structures in a molecule is also interpreted based on the AI in the van Krevelen diagrams. Compounds with AI values $>0.5$ are expected to be aromatic species and those with AI values $>0.67$ are more likely to be condensed aromatic molecules [28], such as polycyclic aromatic hydrocarbons (PAHs), which are often used as indicators to represent the degree of human exposure to hazardous compounds [42]. Significant enrichment is observed for aromatic compounds in the stage three fractions (1.1 and $2.1 \mu \mathrm{m}$ in size) of the main heating samples (see Figure $4 \mathrm{~d}-\mathrm{f}$ ). The main heating season HULISs appear to contain more aromatic compounds (16.7\% aromatics and $5.3 \%$ condensed aromatics). In comparison to the HULISs from the heating season, the HULISs from pre- and postheating seasons appear to have less aromatic (7.9\% and $4.8 \%$ of the total, respectively) and condensed aromatic ( $2.8 \%$ and $1.0 \%$ of the total, respectively) structures. We also found that those aromatic compounds were more enriched in smaller particles (up to $24 \%$ of the total; see Supplementary Materials Tables S3-S5), which supports the potential presence of PAHs and other related compounds in the $\mathrm{PM}_{2.5}$ samples. The compounds with high AI values might also be transferred from traffic into the air as well as from coal power plants and heating. The enriched aromatic constituents in the fine particles might be responsible for the toxicity levels and broaden our understanding of the formation mechanisms for organic aerosols. 


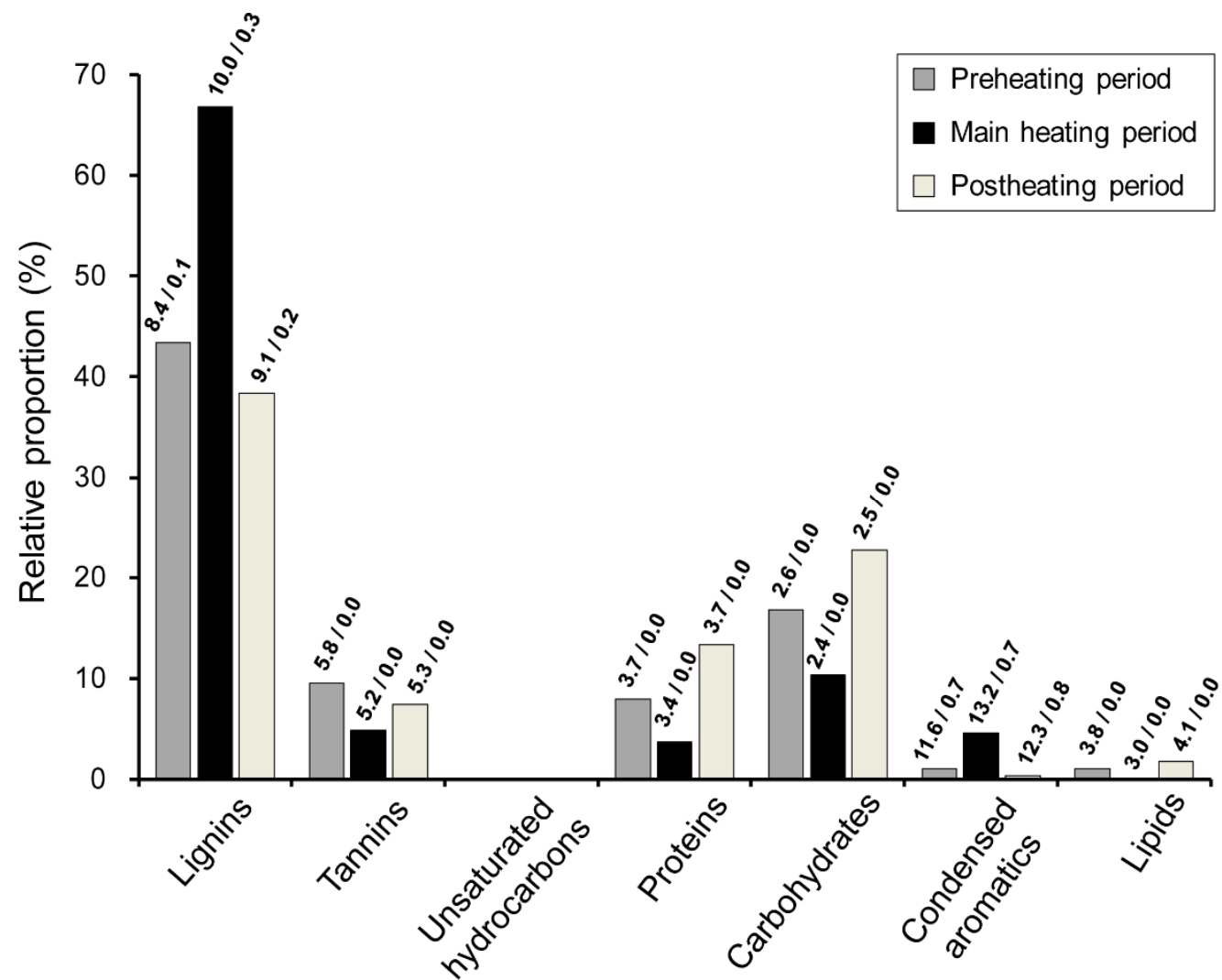

Figure 5. Bar graphs showing the compound class compositions of the size-segregated aerosol-derived HULISs in the stage three fractions (size cut: 1.1-2.1 $\mu \mathrm{m}$ ) during different sampling periods. The numbers on the bars represent the mean DBE and AI values of the corresponding compound classes during each sampling period.

\subsection{Implications of Size-Dependent Chemical Compositions and Their Source Origins}

From the aspect of particle aging events, a larger particle can be considered to be older than a smaller particle because the particle is considered to be growing via various atmospheric reactions $[3,43,44]$. Smaller particles, assuming they are the younger particles, are more dominant from local sources, such as traffic and industries, which are directly emitted into the atmosphere via primary combustion events. On the other hand, larger particles are assumed to be aged particles derived from long-range transport or particle growth in the ambient phase.

In general, the source of organic nitrogen in urban aerosols is often considered to be from traffic because the oxides of nitrogen $\left(\mathrm{NO}_{\mathrm{x}}\right)$ are emitted from the gasoline of vehicles $[45,46]$, which is consistent with the observation that $\mathrm{CHON}$ class species were more enriched in smaller particles. In contrast, it has been reported that the ship fuel sulfur content is approximately $4 \%$, whereas the sulfur contents of inland fuel and gasoline for vehicles are 0.2 and $0.003 \%$ (30 ppm), respectively [47]. Thus, the sulfurs in ambient organosulfates in the Songdo area are supposed to come from ship fuel or Chinese coal, which provides evidence to support the theory that the organosulfates in larger particles are formed by aging in the atmosphere during long-range transport. The chemical properties of $\mathrm{CHOS}$ compounds observed in this study correlate well with the organosulfate species from diesel-derived SOAs [48]. Additionally, based on the van Krevelen plots for the $\mathrm{H} / \mathrm{C}$ versus $\mathrm{O} / \mathrm{C}$ ratios and the assigned chemical formulas from the organic aerosols (as shown in Figure 5), most of the CHOS species appear to belong to protein and carbohydrate classes, whose origins are thought to be from microbes (e.g., marine phytoplankton). Therefore, the neighboring ocean would be one of the potential source origins of the aerosol-carried organosulfates. 
According to an air mass back trajectory analysis, which was employed to investigate the contributions of aerosol source regions (see Supplementary Materials Figure S5), the air mass backward trajectories during the main heating period seemed more prominent in the north wind deriving from China. In contrast, the preheating period exhibited a typical northwest wind while the wind blew around the Yellow Sea and moved towards Songdo during the postheating period. In particular, the air mass during the postheating period was more likely to influence the pollution effect because the wind stayed in a polluted area for a long time and moved over Songdo, which corresponded well with the higher $\mathrm{PM}_{10}$ and $\mathrm{PM}_{2.5}$ levels during the postheating period (Supplementary Materials Table S9). Given these observations, it is more likely that the long-range transport from the East China area significantly contributes to the aerosols collected in the Songdo area regardless of the sampling period.

\section{Conclusions}

In this study, we observed significant differences in the chemical compositional distributions of size-segregated aerosols. The observed chemical properties and molecular class distributions are further analyzed in order to understand their source origins and physicochemical properties. The higher proportion of $\mathrm{CHO}$ and $\mathrm{CHON}$ class molecules and the smaller ratio of sulfur-containing molecules in the smaller ambient particles from size-segregated aerosols might be related to the particle transformation processes and reflect their source origins.

The primary sources of POAs can be divided into natural and anthropogenic biomass burning, including forest fires and domestic heating, fossil-fuel combustion from industries and traffic, soil and road dust, and plant materials. The Songdo area, where the size-segregated aerosol sampling was performed in this study, is exposed to a variety of source origins, such as transportation (i.e., airplanes, ships, and traffic), fossil fuel combustion, biomass from oceans, and so on. Moreover, the relatively high humidity $(>50 \%)$ of the coastal area would be a favorable condition for SOA formation [49,50].

The $\mathrm{CHO}$ and nitrogen-containing $\mathrm{CHO}$ compounds that were found to be enriched in fine particles are more likely to be aromatic unsaturated molecules (i.e., PAHs and aromatic amines), which are supposed to be produced in the primary emissions from traffic or fossil-fuel combustion. Lepri et al. observed the significant enrichment of common organic contaminants (i.e., PAHs and phthalates) in fine aerosol particles that were less than $2 \mu \mathrm{m}$ in diameter [51]. These molecules have been attracting increasing attention due to their severe toxicity and their hazardous nature for human health [52-55]. Therefore, more special attention is needed when high concentrations of these fine particulate pollutants are observed.

The chemical properties of CHOS species, which were identified in this study, have shown similar trends with those of HULIS from aerosol samples in a rural area as demonstrated by Lin et al. (higher H/C and O/C ratios, and smaller DBE and AI values; Supplementary Materials Tables S3-S5) [13]. This provides evidence of more aliphatic and polar, and less aromatic and unsaturated, features. Furthermore, the classification of CHOS compounds into the carbohydrate and protein classes indicates another possibility; that the sulfur-containing organics are derived from the ocean via sea-spray events at the air-sea interface, since the ocean is a well-known reservoir of sulfur-rich dissolved organics [56].

Here, we comprehensively investigated the chemical characteristics of the size-resolved organic aerosols. The results of the size-segregated particles could be utilized to understand particle formation mechanisms and shed light on their toxicity to human health. The detailed compound information and source origins of the aerosol-derived organic constituents were not fully identified yet. Therefore, further studies identifying key components in the size-segregated aerosols and more detailed source apportionments would be necessary for better understanding the complex physiochemical nature of airborne pollutants.

Supplementary Materials: The following are available online at http://www.mdpi.com/2073-4433/10/4/226/s1: Figure S1: Size-resolved samples collected during the preheating, main heating, and postheating periods using an Anderson-type air sampler. Figures S2-S4: Relationships of the particle size with the DBE, AI, H/C, 
and $\mathrm{O} / \mathrm{C}$ values of $\mathrm{CHO}, \mathrm{CHON}$, and $\mathrm{CHOS}$ class species during each sampling period, respectively. Figure S5: Carbon number and DBE plots of the HULISs in particles of stage three fractions. Figure S6: Results for three day air mass back trajectories collected at hourly intervals during each sampling period. Table S1: Summary of the chemical properties of the assigned compositions of HULISs in the size-segregated aerosols. Table S2: Basic air quality information in the Songdo area provided by the Air Korea website operated by the KME. Tables S3-S5: Chemical properties of the assigned molecular classes of HULISs in the size-segregated aerosols collected during the preheating, main heating, and postheating periods, respectively. Tables S6-S8: Chemical properties of the assigned compound classes of HULISs in the size-segregated aerosols collected during the preheating, main heating, and postheating periods, respectively. Table S9: $\mathrm{PM}_{10}$ and $\mathrm{PM}_{2.5}$ levels measured in the Songdo area, South Korea, provided by Air Korea.

Author Contributions: K.S.J. and K.T.P. were involved in research design, A.Y.C., M.C., and H.K. executed the aerosol sample collection, HULIS extraction, and mass spectrometry analysis, K.S.J., T.W.K., and K.T.P. were involved in data interpretation and supervision of the studies, and all authors contributed to writing of the manuscript.

Funding: This research was funded by the National Strategic Project-Fine particle of the National Research Foundation of Korea (NRF) funded by the Ministry of Science and ICT (MSIT), the Ministry of Environment (ME), and the Ministry of Health and Welfare (MOHW) (NRF-2017M3D8A1092223), KOPRI (PE19140), and KBSI (G39110) grants.

Conflicts of Interest: The authors declare no conflict of interest.

\section{References}

1. Ohara, T.; Akimoto, H.; Kurokawa, J.; Horii, N.; Yamaji, K.; Yan, X.; Hayasaka, T. An Asian emission inventory of anthropogenic emission sources for the period 1980-2020. Atmos Chem Phys 2007, 7, 4419-4444. [CrossRef]

2. Monks, P.S.; Granier, C.; Fuzzi, S.; Stohl, A.; Williams, M.L.; Akimoto, H.; Amann, M.; Baklanov, A.; Baltensperger, U.; Bey, I.; et al. Atmospheric composition change—Global and regional air quality. Atmos. Environ. 2009, 43, 5268-5350. [CrossRef]

3. Kroll, J.H.; Seinfeld, J.H. Chemistry of secondary organic aerosol: Formation and evolution of low-volatility organics in the atmosphere. Atmos. Environ. 2008, 42, 3593-3624. [CrossRef]

4. Poschl, U. Atmospheric aerosols: Composition, transformation, climate and health effects. Angew. Chem. Int. Ed. Engl. 2005, 44, 7520-7540. [CrossRef] [PubMed]

5. Hallquist, M.; Wenger, J.C.; Baltensperger, U.; Rudich, Y.; Simpson, D.; Claeys, M.; Dommen, J.; Donahue, N.M.; George, C.; Goldstein, A.H.; et al. The formation, properties and impact of secondary organic aerosol: Current and emerging issues. Atmos. Chem. Phys. 2009, 9, 5155-5236. [CrossRef]

6. Ervens, B.; Turpin, B.J.; Weber, R.J. Secondary organic aerosol formation in cloud droplets and aqueous particles (aqSOA): A review of laboratory, field and model studies. Atmos. Chem. Phys. 2011, 11, 11069-11102. [CrossRef]

7. Bernstein, J.A.; Alexis, N.; Barnes, C.; Bernstein, I.L.; Bernstein, J.A.; Nel, A.; Peden, D.; Diaz-Sanchez, D.; Tarlo, S.M.; Williams, P.B. Health effects of air pollution. J. Allergy Clin. Immunol. 2004, 114, 1116-1123. [CrossRef]

8. $\mathrm{Yu}, \mathrm{H}$. Environmental carcinogenic polycyclic aromatic hydrocarbons: Photochemistry and phototoxicity. J. Environ. Sci. Health C Environ. Carcinog. Ecotoxicol. Rev. 2002, 20, 149-183. [CrossRef]

9. Chowdhury, P.H.; He, Q.; Male, T.L.; Brune, W.H.; Rudich, Y.; Pardo, M. Exposure of lung epithelial cells to photochemically aged secondary organic aerosol shows increased toxic effects. Environ. Sci. Technol. Lett. 2018, 5, 424-430. [CrossRef]

10. Graber, E.R.; Rudich, Y. Atmospheric HULIS: How humic-like are they? A comprehensive and critical review. Atmos. Chem. Phys. 2006, 6, 729-753. [CrossRef]

11. 1Han, H.; Kim, G. Significant seasonal change in optical properties by atmospheric humic-like substances (HULIS) in water-soluble organic carbon aerosols. Atmos. Chem. Phys. Discuss. 2017, 7. [CrossRef]

12. Chen, Q.; Ikemori, F.; Higo, H.; Asakawa, D.; Mochida, M. Chemical Structural Characteristics of HULIS and Other Fractionated Organic Matter in Urban Aerosols: Results from Mass Spectral and FT-IR Analysis. Environ. Sci. Technol. 2016, 50, 1721-1730. [CrossRef] [PubMed]

13. Lin, P.; Rincon, A.G.; Kalberer, M.; Yu, J.Z. Elemental composition of HULIS in the Pearl River Delta Region, China: Results inferred from positive and negative electrospray high resolution mass spectrometric data. Environ. Sci. Technol. 2012, 46, 7454-7462. [CrossRef] [PubMed] 
14. Tan, J.; Xiang, P.; Zhou, X.; Duan, J.; Ma, Y.; He, K.; Cheng, Y.; Yu, J.; Querol, X. Chemical characterization of humic-like substances (HULIS) in $\mathrm{PM}_{2.5}$ in Lanzhou, China. Sci. Total. Environ. 2016, 573, 1481-1490. [CrossRef] [PubMed]

15. Zhao, M.; Qiao, T.; Li, Y.; Tang, X.; Xiu, G.; Yu, J.Z. Temporal variations and source apportionment of Hulis-C in $\mathrm{PM}_{2.5}$ in urban Shanghai. Sci. Total Environ. 2016, 571, 18-26. [CrossRef]

16. Wu, G.; Wan, X.; Gao, S.; Fu, P.; Yin, Y.; Li, G.; Zhang, G.; Kang, S.; Ram, K.; Cong, Z. Humic-Like Substances (HULIS) in Aerosols of Central Tibetan Plateau (Nam Co, $4730 \mathrm{~m}$ asl): Abundance, Light Absorption Properties, and Sources. Environ. Sci. Technol. 2018, 52, 7203-7211. [CrossRef]

17. Liu, J.; Mo, Y.; Ding, P.; Li, J.; Shen, C.; Zhang, G. Dual carbon isotopes ((14)C and (13)C) and optical properties of WSOC and HULIS-C during winter in Guangzhou, China. Sci. Total Environ. 2018, 633, 1571-1578. [CrossRef]

18. Ghosh, S.; Biswas, J.; Guttikunda, S.; Roychowdhury, S.; Nayak, M. An investigation of potential regional and local source regions affecting fine particulate matter concentrations in Delhi, India. J. Air Waste Manag. Assoc. 2015, 65, $218-231$. [CrossRef]

19. Wang, J.; Zhang, M.; Bai, X.; Tan, H.; Li, S.; Liu, J.; Zhang, R.; Wolters, M.A.; Qin, X.; Zhang, M.; et al. Large-scale transport of $\mathrm{PM}_{2.5}$ in the lower troposphere during winter cold surges in China. Sci. Rep. 2017, 7, 13238. [CrossRef]

20. Havers, N.; Burba, P.; Lambert, J.; Klockow, D. Spectroscopic characterization of humic-like substances in airborne particulate matter. J. Atmos. Chem. 1998, 29, 45-54. [CrossRef]

21. Varga, B.; Kiss, G.; Ganszky, I.; Gelencser, A.; Krivacsy, Z. Isolation of water-soluble organic matter from atmospheric aerosol. Talanta 2001, 55, 561-572. [CrossRef]

22. Lin, P.; Yu, J.Z.; Engling, G.; Kalberer, M. Organosulfates in humic-like substance fraction isolated from aerosols at seven locations in East Asia: A study by ultra-high-resolution mass spectrometry. Environ. Sci. Technol. 2012, 46, 13118-13127. [CrossRef]

23. Choi, J.H.; Kim, Y.G.; Lee, Y.K.; Pack, S.P.; Jung, J.Y.; Jang, K.S. Chemical characterization of dissolved organic matter in moist acidic tussock tundra soil using ultra-high resolution 15T FT-ICR mass spectrometry. Biotechnol. Bioprocess. Eng. 2017, 22, 637-646. [CrossRef]

24. Choi, J.H.; Ryu, J.; Jeon, S.; Seo, J.; Yang, Y.H.; Pack, S.P.; Choung, S.; Jang, K.S. In-depth compositional analysis of water-soluble and -insoluble organic substances in fine $\left(\mathrm{PM}_{2.5}\right)$ airborne particles using ultra-high-resolution 15T FT-ICR MS and GCxGC-TOFMS. Environ. Pollut. 2017, 225, 329-337. [CrossRef]

25. Mazzoleni, L.R.; Ehrmann, B.M.; Shen, X.; Marshall, A.G.; Collett, J.L., Jr. Water-soluble atmospheric organic matter in fog: Exact masses and chemical formula identification by ultrahigh-resolution fourier transform ion cyclotron resonance mass spectrometry. Environ. Sci. Technol. 2010, 44, 3690-3697. [CrossRef]

26. Kim, S.; Kramer, R.W.; Hatcher, P.G. Graphical method for analysis of ultrahigh-resolution broadband mass spectra of natural organic matter, the van Krevelen diagram. Anal. Chem. 2003, 75, 5336-5344. [CrossRef]

27. Hockaday, W.C.; Grannas, A.M.; Kim, S.; Hatcher, P.G. Direct molecular evidence for the degradation and mobility of black carbon in soils from ultrahigh-resolution mass spectral analysis of dissolved organic matter from a fire-impacted forest soil. Org. Geochem. 2006, 37, 501-510. [CrossRef]

28. Koch, B.P.; Dittmar, T. From mass to structure: An aromaticity index for high-resolution mass data of natural organic matter. Rapid Commun. Mass Spectrom. 2006, 20, 926-932. [CrossRef]

29. Stein, A.F.; Draxler, R.R.; Rolph, G.D.; Stunder, B.J.B.; Cohen, M.D.; Ngan, F. NOAA's HYSPLIT atmospheric transport and dispersion modeling system. Bull. Amer. Meteor. Soc. 2015, 96, 2059-2077. [CrossRef]

30. Carr, N.; Davis, C.E.; Blackbird, S.; Daniels, L.R.; Preece, C.; Woodward, M.; Mahaffey, C. Seasonal and spatial variability in the optical characteristics of DOM in a temperate shelf sea. Prog. Oceanogr. 2018, 2. [CrossRef]

31. Kowalczuk, P.; Tilstone, G.H.; Zablocka, M.; Röttgers, R.; Thomas, R. Composition of dissolved organic matter along an Atlantic Meridional Transect from fluorescence spectroscopy and Parallel Factor Analysis. Mar. Chem. 2013, 157, 170-184. [CrossRef]

32. Yue, D.; Hu, M.; Wu, Z.; Wang, Z.; Guo, S.; Wehner, B.; Nowak, A.; Achtert, P.; Wiedensohler, A.; Jung, J.; et al. Characteristics of aerosol size distributions and new particle formation in the summer in Beijing. J. Geophys. Res. 2009, 114, D00G12. [CrossRef]

33. Ueda, S.; Miura, K.; Kawata, R.; Furutani, H.; Uematsu, M.; Omori, Y. Number-size distribution of aerosol particles and new particle formation events in tropical and subtropical Pacific Oceans. Atmos. Environ. 2016, 142, 324-339. [CrossRef] 
34. Al-Kindi, S.S.; Pope, F.D.; Beddows, D.C.; Bloss, W.J.; Harrison, R.M. Size-dependent chemical ageing of oleic acid aerosol under dry and humidified conditions. Atmos. Chem. Phys. 2016, 16, 15561-15579. [CrossRef]

35. Smith, J.N.; Dunn, M.J.; VanReken, T.M.; Iida, K.; Stolzenburg, M.R.; McMurry, P.H.; Huey, L.G. Chemical composition of atmospheric nanoparticles formed from nucleation in Tecamac, Mexico: Evidence for an important role for organic species in nanoparticle growth. Geophys. Res. Lett. 2008, 35, 2-6. [CrossRef]

36. Seinfeld, J.H.; Erdakos, G.B.; Asher, W.E.; Pankow, J.F. Modeling the formation of secondary organic aerosol (SOA). 2. The predicted effects of relative humidity on aerosol formation in the alpha-pinene-, beta-pinene-, sabinene-, delta 3-carene-, and cyclohexene-ozone systems. Environ. Sci. Technol. 2001, 35, 1806-1817. [CrossRef]

37. Vasconcelos, L.A.P.; Macias, E.S.; White, W.H. Aerosol composition as a function of haze and humidity levels in the Southwestern U.S. Atmos. Environ. 2003, 28, 3679-3691. [CrossRef]

38. Tong, H.; Kourtchev, I.; Pant, P.; Keyte, I.J.; O'Connor, I.P.; Wenger, J.C.; Pope, F.D.; Harrison, R.M.; Kalberer, M. Molecular composition of organic aerosols at urban background and road tunnel sites using ultra-high resolution mass spectrometry. Faraday Discuss. 2016, 189, 51-68. [CrossRef]

39. Shakya, K.M.; Louchouarn, P.; Griffin, R.J. Lignin-derived phenols in Houston aerosols: Implications for natural background sources. Environ. Sci. Technol. 2011, 45, 8268-8275. [CrossRef]

40. Ravindra, K.; Sokhi, R.; van Grieken, R. Atmospheric polycyclic aromatic hydrocarbons: Source attribution, emission factors and regulation. Atmos. Environ. 2008, 42, 2895-2921. [CrossRef]

41. Chang, K.F.; Fang, G.C.; Chen, J.C.; Wu, Y.S. Atmospheric polycyclic aromatic hydrocarbons (PAHs) in Asia: A review from 1999 to 2004. Environ. Pollut. 2006, 142, 388-396. [CrossRef] [PubMed]

42. Jiang, B.; Liang, Y.; Xu, C.; Zhang, J.; Hu, M.; Shi, Q. Polycyclic aromatic hydrocarbons (PAHs) in ambient aerosols from Beijing: Characterization of low volatile PAHs by positive-ion atmospheric pressure photoionization (APPI) coupled with Fourier transform ion cyclotron resonance. Environ. Sci. Technol. 2014, 48, 4716-4723. [CrossRef] [PubMed]

43. Petters, M.D.; Prenni, A.J.; Kreidenweis, S.M.; DeMott, P.J; Matsunaga, A.; Lim, Y.B.; Ziemann, P.J. Chemical aging and the hydrophobic-to-hydrophilic conversion of carbonaceous aerosol. Geophys. Res. Lett. 2006, 33, L24806. [CrossRef]

44. Denjean, C.; Formenti, P.; Picquet-Varrault, B.; Camredon, M.; Pangui, E.; Zapf, P.; Katrib, Y.; Giorio, C.; Tapparo, A.; Temime-Roussel, B.; et al. Aging of secondary organic aerosol generated from the ozonolysis of

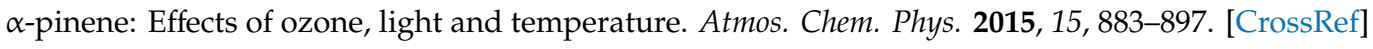

45. Carslaw, D.C. Evidence of an increasing $\mathrm{NO}_{2} / \mathrm{NO}_{X}$ emissions ratio from road traffic emissions. Atmos. Environ. 2005, 39, 4793-4802. [CrossRef]

46. Yli-Tuomi, T.; Aarnio, P.; Pirjola, L.; Mäkelä, T.; Hillamo, R.; Jantunen, M. Emissions of fine particles, $\mathrm{NO}_{\mathrm{x}}$ andCO from on-road vehicles in Finland. Atmos. Environ. 2005, 39, 6696-6706. [CrossRef]

47. Cho, K.D.; Kim, J.S. The Status of the Atmospheric Environment and Air Quality Management Measures of the Port. of Incheon; The Incheon Institute: Incheon, Korea, 2009.

48. Blair, S.L.; MacMillan, A.C.; Drozd, G.T.; Goldstein, A.H.; Chu, R.K.; Pasa-Tolic, L.; Shaw, J.B.; Tolic, N.; Lin, P.; Laskin, J.; et al. Molecular Characterization of Organosulfur Compounds in Biodiesel and Diesel Fuel Secondary Organic Aerosol. Environ. Sci. Technol. 2017, 51, 119-127. [CrossRef] [PubMed]

49. Zhang, H.; Surratt, J.D.; Lin, Y.H.; Bapat, J.; Kamens, R.M. Effect of relative humidity on SOA formation from isoprene/NO photooxidation: Enhancement of 2-methylglyceric acid and its corresponding oligoesters under dry conditions. Atmos. Chem. Phys. 2011, 11, 6411-6424. [CrossRef]

50. Emanuelsson, E.U.; Watne, A.K.; Lutz, A.; Ljungstrom, E.; Hallquist, M. Influence of humidity, temperature, and radicals on the formation and thermal properties of secondary organic aerosol (SOA) from ozonolysis of beta-pinene. J. Phys. Chem. A 2013, 117, 10346-10358. [CrossRef]

51. Lepri, L.; Bubba, M.D.; Masi, F.; Udisti, R.; Cini, R. Particle size distribution of organic compounds in aqueous aerosols collected from above sewage aeration tanks. Aerosol Sci. Technol. 2000, 32, 404-420. [CrossRef]

52. Bostrom, C.E.; Gerde, P.; Hanberg, A.; Jernstrom, B.; Johansson, C.; Kyrklund, T.; Rannug, A.; Tornqvist, M.; Victorin, K.; Westerholm, R. Cancer risk assessment, indicators, and guidelines for polycyclic aromatic hydrocarbons in the ambient air. Environ. Health Perspect. 2002, 110, 451-488.

53. Hauser, R.; Calafat, A.M. Phthalates and human health. Occup. Environ. Med. 2005, 6, 806-818. [CrossRef] [PubMed] 
54. Benjamin, S.; Masai, E.; Kamimura, N.; Takahashi, K.; Anderson, R.C.; Faisal, P.A. Phthalates impact human health: Epidemiological evidences and plausible mechanism of action. J. Hazard. Mater. 2017, 340, 360-383. [CrossRef] [PubMed]

55. Cao, Z.; Wang, M.; Chen, Q.; Zhu, C.; Jie, J.; Li, X.; Dong, X.; Miao, Z.; Shen, M.; Bu, Q. Spatial, seasonal and particle size dependent variations of $\mathrm{PAH}$ contamination in indoor dust and the corresponding human health risk. Sci. Total Environ. 2019, 653, 423-430. [CrossRef] [PubMed]

56. Ksionzek, K.B.; Lechtenfeld, O.J.; McCallister, S.L.; Schmitt-Kopplin, P.; Geuer, J.K.; Geibert, W.; Koch, B.P. Dissolved organic sulfur in the ocean: Biogeochemistry of a petagram inventory. Science 2016, 354, 456-459. [CrossRef] 